\title{
Karl Barth's male-female order as asymmetrical theoethics
}

\author{
Yolanda Dreyer \\ Department of Practical Theology \\ University of Pretoria
}

\begin{abstract}
This article is to argues that Karl Barth's revelation-based theology represents male bias entrapped within patriarchal Christian tradition. The rigid way of using the revelation-based model in exegesis and theology goes against the grain of Barth's otherwise flexible epistemology. It is particularly evident in the connection between Barth's theoetics and his view on the subordination of women. In two articles written from a gender critical perspective the focus of the first article is on Barth's asymmetrical theoethics and that of the second on the disparity in his dogmatics. The aim of the first article is to trace the influence of the Christian tradition (including early Christianity) on his theology. The aim of the second article is to explain Barth's dogmatic disparity as the product of his neoorthodox understanding of Reformed tradition.
\end{abstract}

\section{INTRODUCTION}

Karl Barth (1886-1968) has considerably influenced theology up to the present day. Barth's ([1932-1967] 1936-1969) monumental work, Die Kirchliche Dogmatik, is structured on the basis of the idea that dogmatics and ethics form a dialectic word pair (see inter alia Hartwell 1964). Jörg Lauster (2004:263) refers to this structure as the "eigenständige Architektonik des Werks". For Barth, an ethical insight will always be based on a theological premise, while theology always has ethical implications. This is why, in Barthian studies, terms such as "theoethics" (Robert Willis, in Bourquin 1972:675) and "special ethics" (McKelway 1979:345-357) have been coined. Barth ( $C D$ III.4.6) himself uses the term "special ethics":

\footnotetext{
"Special ethics" is sometimes taken to mean the understanding of the command of God as a prescribed text, which, part by written and partly unwritten, is made up of biblical texts in which there are believed to be some universally binding divine ordinances and directions, of certain propositions again presumed to be universally
} 
valid, of the natural moral law generally perceptible to human reason, and finally of particular norms which have been handed down historically in the tradition of Western Christianity and which lay claim to universal validity. The grouping and blending of the various elements in the text may vary, the Bible, natural law or tradition predominating. The essential point is that God's command is regarded as in some sense a legal text known to the ethical teacher and those whom he has to instruct.

This citation (my emphasis) highlights the flexibility in Barth's thinking (cf Deegan 1962:400-412). Sometimes the centre of his theologising would be the tangible "biblical text" (see Bromiley 1979). In other instances it could be either "natural moral law" or the "tradition of Western Christianity" (cf Rae 1972:412-422; Moltmann-Wendel \& Moltmann 1981:354-365). From a perspective of postmodern epistemology, such flexibility is praiseworthy. It is from such a perspective that Mark Wallace commends Barth's placticity even though referring to the "older revelation-based theologies", which include Barthian theology. Wallace ([1990] 1995:114) puts it as follows:

In our period the Bible has emerged from being a stable book with a central message to being a complicated text of "intertext" with no reliable center. A revisionary notion of revelation, then, will work on the basis of the dual recognition that this category should, indeed, be the linchpin of the contemporary Christian theology based on the biblical witness, but it will also maintain that this witness is fraught with more ambiguity and multiple meanings than previous theologians and exegetes had thought to be the case.

Wallace (1995:116) shows that Barth's epistemology of "relational truth" does not lead to relativism: "Regarding this issue, I find Barth's hermeneutic to be especially powerful and acutely sensitive to postmodern insight ...."

However, in some circles Barth has been criticised that his "Biblical Theology" had been unwittingly formed by positivism. His positivistic Chistcentric hermeneutic has been labelled "neoorthodox" (see Poland 1985:472) and "postcritical" (see Smend 1966:215-237). Eberhard Jüngel (1982:91-98), softens the "postcritical" to "metacritical". Even though the criticism of positivism may be valid, Barth did not theologise primarily from biblical exegesis as such (see Sykes 1982; Bennett 1962; Von Balthasar 1971). His "theoethics" was rather the product of Western Christian tradition, whereas his "dogmatism" (based on biblisistic thinking) was the product of his having absorbed the Reformed tradition into a Hegelian (see Henrich [1967] 1971) dialectic framework.

Barth's theology of revelation "from above" in Jesus Christ collided with Schleiermacher's emphasis on the experience of the believer, which Barth 
labelled as thinking "from below" (cf Crouter 2005:14). Present-day theologians such as John Macquarrie (1990) and Robert Dawson (Dawson) understand Barth's theology as an "objection to the humanistic approach epitomized by Schleiermacher" (Dawson 2007:19). Macquarrie (1990:279) sees Barth's understanding of Schleiermacher as follows:

[Schleiermacher's theology] was mistaken [according to Barth] in basing itself on human experience, because this was to overlook the fact that human nature is flawed by sin and cannot find the way to God; and it was further mistaken in its attempts to represent Jesus Christ as virtually a natural development in the history of humanity. In Barth's view, religion [as understood by Schleiermacher] never gets out of human subjectivity; [Schleiermacher's theology] is a search for God which leads only to idols fabricated by our own minds.

According to Barth (see esp Barth's [1953], The resurrection of the dead, together with Barth's [1933] revised Romans), people can "know" God, "only on the basis of divine revelation" (Dawson 2007:33). Dawson (2007:33) explains Barth's conviction as follows: "Whereas human beings could in no way apprehend the divine, God has revealed himself in truth in the resurrection of Jesus Christ' (my emphasis). Dawson (2007:113-136) sees the "Resurrection in CD IV as the movement from Jesus Christ to others" (my emphasis). Herein lies the origin of Barth's theoethics (see inter alia Torrance 1976).

Richard Crouter (2005:4) calls Barth's theology the "antiSchleiermacher revolution". Whereas Schleiermacher's approach could make room for the equality of women (see Richardson 1991:455-472; cf Ellison 1990:17-44; Crouter 2005:110-117; Beiser 2005:63), Barth's theological model functioned as an "ideology" when applied to gender relations. Beiser (2005:63) formulates Schleiermacher's contribution as follows:

One of the most important aspects of Schleiermacher's ethic of love was its emphasis upon sexual equality, more specifically the right of women to realize their own individuality as well as men. The most important expression of this credo is Schleiermacher's catechism for women in Athenaeums Fragmente No.364. Since the romantic call for sexual equality was primarily moral rather than political - the romantics were not advocating women's suffrage or right to work it would be anachronistic to see them as pioneers of contemporary feminism. Still, it would be unjust to underrate the romantic contribution [e.g. of Schleiermacher] to sexual equality and emancipation. 


\section{Karl Barth's male-female order as asymmetrical theoethics}

Barth's revelation based theology is diametrically opposed to Schleiermacher's insights in this regard. Though Barth describes his view as "theological", it clearly represents male bias, human prejudice and his entrapment within patriarchal Christian tradition. Barth's model based on the "Christ revelation", is consistently applied in such a way that it objectifies people. When believers are objectified and their experience neglected, their possibility of an authentic existence in the presence of God is undermined. This rigid way of using a model, goes against the grain of Barth's otherwise flexible epistemology and he indeed becomes uncritical (see Smend 1966:215-237) in his exegesis of Biblical texts regarding gender. This can be seen especially in the connection between Barth's theoetics and his view on the subordination of women (cf Mercandante 1978).

A similar phenomenon can be detected in Barth's discussion of relationships - between God and human beings, and of people among themselves. Relationships is an ontological matter which Barth "deontologised" and made more flexible by using analogical (comparative) rather than ontic (static) concepts to explain it. Ontic language is unchangeable ("this is how it is"), whereas analogical language creates openness to possibilities. Relationships are not static and are therefore best served by non-ontological language. The philosopher, Paul Ricoeur (1979:219), builds on Barth's insights when he says: "For the philosopher, to listen to Christian preaching is first of all to let go (se depouiller) of every form of ontotheological knowledge." This is why Karl Barth replaced analogia entis (the static nature of relationship) with analogia fidei, which denotes a relationship where human beings respond to God's grace with faith. The relationship is not static, because the believer has the freedom to respond to God in faith. The believer, however, remains subordinate to God in this relationship, which means that the analogia relationis is a unilateral covenant (with an inherent inequality).

Barth also uses the concept analogia relationis to refer to relationships among people. When applied specifically to the relationship between male and female, Barth understands the analogia relationis as a relationship of free choice by both partners. However, freedom is compromised by his idea that woman remains subordinate to man, as human beings are subordinate to God. Rather than placing relationship and freedom in the centre, he applies his model in a rigid way and in so doing contaminates the essence of freedom. It constitutes a disparity in Barth's dogmatic method. According to Emma Jutes (1978:52), this is to "mix apples and oranges". For a human being to believe in God, is a qualitatively different relationship from that of one human being with another. 
In two articles from a gender critical perspective (see the work of Ford 1984; Moltmann-Wendel \& Moltmann 1981; cf also Justes 1978:42-54; Tribble 1978), I focus in the first on Barth's asymmetrical theoethics and in the second on the disparity in his dogmatics. The aim of the first article is to trace the influence of the Christian tradition (including early Christianity) on his theology. The aim of the second article is to explain Barth's dogmatic disparity as the product of his neoorthodox understanding of Reformed tradition.

\section{PREMISE}

Early Christianity is studied by means of canonical and apocryphal New Testament writings and their Wirkungsgeschichte. The first written texts are those of the apostle Paul. According to Paul (in the Letter to the Galatians), categories such as ethnicity (Jew or Greek) and sex/gender (male or female) were irrelevant in the new creation that dawned in Jesus Christ. However, the question is whether the liberation from such social and human categories in early Christian tradition contributed to changing the place and role of women in society and the church. In the pre-modern, patriarchal social context of the early Christians, the submission of married women to their husbands was a given. Christians with an Israelite background mystified and legitimated this social phenomenon by means of religion. A Biblical concept that was used in such a way from early Christianity right up to the theology of Karl Barth, is "the image of God".

The male head of the household reflected the "the image of God" and therefore had authority over all his human and material possessions, including his women, children and slaves. Male slaves and children could become heads of households who then had women and children under them (see Osiek 2005:352-359). Only women were by nature excluded from any form of authority and were in effect excluded from reflecting the image of God. Some followers of Jesus in early Christianity did, however, regarded marriage was as a part of the present earthly dispensation and not as part of the heavenly dispensation which is yet to come (Mt 22:23-33 and parallel synoptic texts). 
A "gnostic"1 development (cf Thatcher 1999:136) was the idea that, in the divine realm, an a-sexual soul existed separately from a sexual body (see King 2003). The image of God in human beings is located in the soul, not in the body. The disembodied souls of men and women are equal. This is the state of restoration which will be brought about by Christ. Women in their disembodied state of being soul only can then also reflect the image of God. Many Christians understood Galatians 3:28 in this "gnostic" fashion (cf Børresen 1991a:197).

In their social relations women as embodied beings were not included in the image of God. This view culminated in the idea that women were subordinate to men in the earthly dispensation as men were subordinate to God (1 Cor 11:3). Despite Karl Barth's emphasis on God's revelation in and through Jesus Christ as "recreation", his "ethics of creation" contributed to perpetuate gender inequality deep into the twentieth century. Thatcher (1999:88, note 30) puts it as follows: "According to Karl Barth and many contemporary evangelicals, the subordination of women to men is ordered by God at creation and cannot be changed." In his Church Dogmatics (III.4.52) Barth lays the foundation for his "ethics of creation" which builds on his understanding of the biblical notions of reconciliation and redemption (cf Ford 1984:68). His Church Dogmatics was, however, never completed.

In $C D$ II.2 Barth discusses ethics, which he understands as the command of God, grounded in Jesus Christ. God and humanity come together in Jesus. This is the way in which God assumes responsibility for humanity ( $C D$ 11.2.564; see Ford 1984:68). Barth based his theological ethics on God's convenant with human beings entered into at creation, and on the recreation in Jesus Christ. God chose people and also asks something of them - that they should live according to God's law. This does not invalidate grace. God, who chooses people on account of grace, rules over their lives and commands their obedient response (see Bromiley 1979:99; cf Ford 1984:69). Ethics, for Barth, is therefore not a general matter, but belongs specifically with the doctrine of God as creator and recreator. God elects (grace) and commands (ethics). Whereas Schleiermacher based his

\footnotetext{
${ }^{1}$ Any attempt to "define" of what "Gnosticism" could have meant in the first two centuries CE, is easier said than done (see Roukema 1998; Markschies 2003). One can probably not do more than design a "typology" of the multi-dimensional phenomenon called "Gnosticism". The following 5 common apects of "Gnostic thinking" can be discerned (though not all texts display all 5): "gnosis" is about insight into (a) the "nature" of God, (b) the origins of "spiritual powers", (c) the origins of creation, (d) the purpose of existence on earth, and (e) the way in which "spiritual redemption" can be obtained (Roukema 1998:13). Human beings have a latent/hidden/divine/eternal/ heavenly core of which the origin lies with "God Almighty". The purpose of life on earth is to become aware of this origin and to be reconciled with "God Almighty" through "true gnosis". This redemption takes place already in the earthly life, not only after death (see Van Aarde 2005:826-850).
} 
theological ethics (see Beiser 2005:58-72) on love - God's love and believers' response in love - Barth based his theological ethics on covenantal creational theology.

According to him, human actions (ethics) can be "good" if they flow from the knowledge of having been elected by God in Christ (gospel/grace) (Barth, CD II.2.598-609; cf Weber [1963] 1967:105-107). In other words, the Christian ethical imperative - in Lutheran terms the "law"/Ten Commandments - cannot be separated from the indicative of God's grace. It is precisely God's grace that demands of human beings to actively serve one another. The "ethics of grace" is not coercive but is an "ethics of freedom" (CD III.4; see Ford 1984:71-72; Hartwell 1964:158, 160). This freedom is given whenever God speaks through God's word, and is received when people hear this Word and freely choose to obey. God's commands and the ethics of believers do not consist of fixed and general principles (laws) which are then only applied to new situations. God speaks afresh to new situations (see Ford 1984:73; cf Hartwell 1964:162-163). When new situations are examined in light of God's commands, this is done from a basis of freedom and grace (Ford 1984:74; cf Whitehouse 1952:337-338). We have seen that, for Barth (CD III.4.6), the notions of "biblical texts", "natural moral law" and "the traditions of Western Christianity" form a dialectic combination. One does not function without the other. Contrary to this dialect, a casuistic method of just applying set norms would amount to "an amalgam of biblical texts, natural law and Western tradition" (Ford 1984:75). This has consequences for the concrete experience of human beings. When the Bible, natural law (creation ordinances) and tradition are mixed together in this way, they lose their dialectic dynamics (separate entities which give meaning to one another by remaining in a relationship of critical tension).

The Bible becomes divine law. The consequence is that the Bible as Word of God forms a direct relationship to God, which means that God is objectified as Bible. However, Barth's perspective on Scripture is clear. There is an indirect relationship between Word of God and God-self. According to Lauster (2004:264) the Grundmelodie of Barth's perspective on Scripture (Schriftlehre) is the refrain: "Gottes Wort is Gott selbst in der heiligen Schrift" (KD I.2.505). Lauster (2004:264) puts it as follows: "Die Schrift ist gerade als Zeugnis von Gottes Offenbarung Gottes Wort. Der zo gebrauchte Zeugnisbegriff dient in erster Linie dazu, das Verhältnis von Schrift und Wort Gottes als differenzierte Einheit [indirect relationship] zu begreifen" (my emphasis). If this differentiation lacks, creation ordinances become divine laws. Creation ordinances, witnessed to in the Bible, become divine norms. 
Creation ordinances become divine norms. Tradition is mystified as God-given. This has the effect of violating the freedom of human beings. Believers become subject to the law rather than to grace. They still cannot discern the divine imperative in a specific ethical situation (Whitehouse 1952:340) since tradition (social constructs) and natural law (primordial essentials) keep changing, whereas the Bible is a historical (fixed) document from the past. Barthian hermeneutics has influenced present-day "narrative theologians" (see e.g. Wallace 1995:89-92) to engage meaningfully with biblical narratives in a dialectic manner. This has led to postmodern cultural criticism and ideology criticism, for example by Peter Berger (1979). This turn in "hermeneutic tradition as reconfigured by Heidegger, Gadamer and Ricoeur" - as Dan Stiver (2007:145-156) describes it - is formulated by Martin Warner (2007:5-6), following Charles Taylor (2007:57-76), as follows:

Charles Taylor's [2007:57-76] counter-narrative to those ["available conventions as well as ... ideologies and vested interest"] that lie behind his "closed world structures" [legitimated by masternarratives] may itself be seen as an exercise in the hermeneutics of suspicion. Thus the perspectives now made available by contemporary hermeneutic theory enable us to see the more limited framework as just that. By rooting texts in the broader context of human horizons, cultures, interests and readers, they provide us with "phronetic" [Aristotle's term, deployed in ethics for applying general rules to particular situations] criteria to judge when we need go beyond conventional readings, when to engage in critique as a part of interpreting them, and perhaps even make sense of the notion that the dynamic of a [biblical] text may point us to forms of understanding unavailable to its [biblical] author.

Although influenced by Barth (and among others Paul Ricoeur), this postmodern hermeneutics of suspicion represents a perspective on Scripture that goes far beyond Barth's own intention. For Barth an "ethical" life is one lived in God's presence, receiving the command about how to be in relationship with others directly from God. He puts it as follows: "Only as the vertical intersects a horizontal can it be called vertical. We have thus to consider the horizontal as well, and therefore the constancy and continuity both of the divine command and human action" (Barth $C D$ III.4.17). "Special ethics" for Barth is about finding the appropriate norms for concrete situations. These norms are discerned in an engagement with God in Jesus Christ. This happens where the Word of God is proclaimed and believed. Concrete situations are where God meets humanity (see Deegan 1962:405). Barth (CD III.4.26-27) put it as follows: 
Since the ethical event as an encounter of the concrete God with concrete man does not take place in empty space but in that defined by the concreteness of both these partners and their encounter, ethics, too, does not stand before something which is general and cannot be expressed in particular terms, but it can and must become special ethics.

Though the social context of people is important to Barth, praxis may not determine the nature of the norm (God's commands). People receive guidelines from God's revelation as to what God commands for their real lives (Bromiley 1979:157). This "special ethics" is grounded in the doctrine of creation: God creates and recreates - reconciles and redeems. God gives humanity freedom in their relationship with God (CD III.4.53), in koinonia (fellowship) with others ( $C D$ III.4.54), freedom for life (CD III.4.55) - but this is a freedom inhibited by responsibility before God and toward other people ( $C D$ III.4.56) (see Ford 1984:79).

Freedom is what keeps this ethics from being legalistic. In other words, ethics for Barth is not about a set of laws deduced from Scripture, but rather that humanity should reflect on how to use the gift of freedom well (Rae 1972:416; cf Ford 1984:80). This concept of freedom is marred when Barth applies "fellowship" to the relationship between men and women. Then it becomes an ideology which sentences women to bondage. Such a "theology of ethics" necessitates a hermeneutics of suspicion. It becomes an imperative to question Barth in this respect. A cultural-critical reading of Barth's theology shows that Barth did not escape the trap of patriarchal subordiantion of women which is as old as the Christian tradition. This becomes especially clear with regards to marriage, which according to Martin Luther, from whom Barth inherited his law/gospel (imperative/indicative) dialectic, resorts under "creation ordinances" (cf Buitendag 2007:445-461). In this respect, Buitendag (2007:445-461) calls Barth's exposition of Ephesians 5 with reference to marriage, the worst exegesis in his entire Church Dogmatics.

\section{IN THE BEGINNING}

In the earliest Christian communities patriarchal relations were regarded by some as the norm for Christian leadership. Others viewed unmarried women as free from male dominance (see Osiek 2006:832- 834). Women and patronage), who could therefore have the authority to be leaders and teachers. This conflict of opinions is attested to in the opposing works of 1 Timothy and the Acts of Paul and Thecla (see Ruether 1991:266).

The subordination of women was influenced by the early Christians' acceptance of the Platonic tripartite sarx, psyche en pneuma. The psyche was 


\section{Karl Barth's male-female order as asymmetrical theoethics}

the sensual part of the soul and mediator to the body. Femaleness was equated with bodiliness and maleness with reason. Spiritual maturity was regarded as a male attribute, whereas the more base aspect of sensuality was seen as female. Those few women who were viewed as "spiritually developed" could be free from subordination to males and could have spiritual authority (see Ruether 1991:267).

"Gnostic" thinking was dualistic. ${ }^{2}$ The body was regarded as the opposite of the intelligent spiritual aspect, which was seen the essence of a person's authentic humanity, and in which the image of God was portrayed. The difference between men and women manifested in their bodiliness as well as in the higher spiritual sphere. The male element of spirituality was called pneuma - see the apologetics of Tatianus, Oratio ad Graecos (ed by E J Goodspeed 1915:268-305) and Origenes, De principiis (ed by Görgemanns, H \& Karpp 1976:462-560, 668-764) and nous (see, among others, the apologetics in Justinus, Dialogus cum Tryphona 3.7-4.5, ed by E J Goodspeed 1915:90-265; The Teachings of Silvanus 92.19-20-93.28-32, in Evans, G A, Webb, R L \& Wiebe, R A (eds) 1993, Nag Hammadi texts \& the Bible: A Synopsis \& index, p 315). Pneuma was considered higher than the female element of psyche, which was responsible for weakness and the tendencies toward sensuality (Tatianus), passion and anger (Origenes, The Teachings of Silvanus). The difference in sex was used to explain the inner workings of human beings.

Barth whose thought was rooted in the theology of the patristic fathers, ironically enough shows "Gnostic tendencies" when he, 2000 years later, confirms gender inequality when he refers to the "inner workings of human beings". For the church fathers, for the "gnostics" and for Karl Barth hierarchy was always present. Balance in "Gnosticism" could only be attained when the lower more base part of humanity was controlled by the higher, better part. Only the male elements of nous or pneuma could reflect the "image of God" in this earthly dispensation. In the next world, the perfect Christ-like humanity, the arche, which is the perfect reflection of the image of God, is not differentiated in male and female.

If a woman wanted to develop out of her lowly state to a higher level of spirituality and morality, the only way was to "become male" - an expression found in "Gnostic" texts or texts influenced by "Gnostic" teaching. The opposite was also possible. A man who regressed from his natural higher spiritual state to a state of moral degeneration could "become female". Though in some Nag Hammadi documents "sex change is applied to both sexes (also in Clemens Alexandrinus, Excerpta ex Theodoto, ed by $\mathrm{F}$

\footnotetext{
${ }^{2}$ See again footnote 1.
} 
Sagnard [1948] 1970:52-212), in the majority of evidence it is only applied to women (see, e.g., Franzmann 1996:60-69). For example, as Zostrianos 13.58 puts it: Flee from the madness and the bondage of femaleness, and choose for yourselves the salvation of maleness" (in Franzmann 1996:67-68; cf inter alia The Gospel of Thomas 114, in Evans et al (eds) 1993, Nag Hammadi texts \& the Bible: A Synopsis \& index, p 143-144). According to Gasparro (1991:157-158), these formulations from the social environment of the Bible, influenced the long standing tradition in Christianity where, in spite of Genesis $1: 27$, the image of God is limited to maleness.

Barth's "special ethics" liberated woman from this bondage, but he still endorsed her unequal status in relation to man. This represents a perpetuation of the church fathers' evaluation of women. In this kind of theology, women are seemingly appreciated, yet in a patronising way that can still be seen in Barth's attempt to elevate women as bearers of God's image similar to men. The church fathers also fell into this trap of patronising women.

\section{ACCORDING TO THE FATHERS}

In early Christianity the ideas of the patristic fathers on maleness, femaleness and spiritual worthiness go back to the term "perfect man" (teleios aner) in Ephesians 4:13. Clemens Alexandrinus was the first Church Father who gave prominence to this expression. His writings date from the end of the second to the beginning of the third century CE. In his Stromata VI.100.3 (ed by O Stählin, L Früchtel \& U Treu, 2 [1960], pp 3-518; 3 [1970], pp 3-102), Clemens Alexandinus refers to a woman who freed herself from being bound to the "flesh" and who attained perfection just like her husband. In Clement's opinion the soul was not male of female (see Vogt 1991:172-173, 177).

According to Origenes, the woman who had become male was no longer female, but was the perfect male-female Origenes (De Principiis, III.IV.1, ed by Görgemanns \& Karpp 1976:462-560, 668-764). This polarisation of male and female has consequences for Origenes' anthropology and ethics. The male soul (animus) or spirituality was considered higher and of more value than the lower anima or senses. In addition to this, moral characteristics were classified as male or female. Weakness, sensuality, laziness, dependence could be directly related to sin and were categorised as feminine. Sex differences were spiritualised. Authentic sex was seen as a matter of the inner human being. Not the body, but a person's moral and spiritual quality determined whether she or he was regarded as "male" or "female". A woman of higher spiritual quality could become a man and a degenerate man could become a woman and will be lost (Vogt 1991:178). 
Dydymus Caecus ("the Blind") of Alexandria, in his $4^{\text {th }}$ century exegesis of Genesis 1:27b (In Genesim, ed by P Nautin \& L Doutreleau, Didyme l'Aveugle: Sur Genesé 1[1976] 32-332), regards the sexes are equal. The only difference is in their different roles regarding precreation. Dydymus affirmed the Alexandrine idea that women reflect the image of God. However, according to him, there is a difference between the male and the female soul. The male soul is superior and the female soul inferior. The male soul has a leadership component, whereas the female soul is the passive receiver. Such a "relationship" is equally disrespectful of women as Barth's notion of analogia relationis (see Dreyer 2007:1523-1547). Like Barth, Dydymus cemented this asymmetry in a "creation ordinance" and made it into a "natural moral law". In the material world a person is either man or woman. This is a fact that cannot be changed. In the spiritual world a woman can become male and thereby attain the authority to lead and teach others. The soul can reach perfection only by becoming male (Vogt 1991:180). In Jerome's commentary on Ephesians (in Vogt 1991:181) he puts it as follows: "So long as a woman is subject to childbirth and the care of children, she is different from a man, like the body is different from the soul. If she chooses to serve Christ and not the world, however, she ceases to be a woman and can be called a man, as we all crave to become perfect man." If a woman should, for instance, choose to lead an ascetic life, she would not be considered female any longer, but would be called male. This view of maleness becomes prominent in asceticmonastic literature of the fourth and fifth centuries. According to these writings these "perfect women" called themselves gunaikes andreiai (see Vogt 1991:181)

This trend continued in early hagiographic literature (biographies of saints) emphasises that holiness transcends femaleness. To call a woman "male" was seen in a positive light. In many sources social contact between the sexes is explained in terms of metaphors which either neutralise or change a person's sex. When a woman is called "male", it is implies that female saints have equal authority to males. The term "male" often refers to the perfect and complete state of human nature in which sex has been transcended. "Female", on the other hand, always refers to inferior beings. In this literature sex is not seen as a physical given, but as something that

\footnotetext{
${ }^{3}$ Jerome, ed J-P Migne ([1963] 1974), Patrologia Latina 26.567: mulier esse cessabit, et dictur vir, quia omnes in perfectum virum copimus occurrere (English translation in Vogt 1991:181) (cf Schade, L [Hrsg] 1914. Ausgewählte historische, homiletische $u$. Dogmatische Schriften des heiligen Kirchenvaters Eusebuis Hieronymus, aus dem latyeinischen übersetzt.
} 
resides in the innermost part of a person's humanity and which can change. Sex then depends on spiritual progress which, in turn, determines salvation (Vogt 1991:182-183, 185).

Degredation of women's sexuality was much elaborated on by the patristic fathers Justin (died ca $165 \mathrm{CE}$ ) and Irenaeus (died ca $200 \mathrm{CE}$ ) concurred that Eve's sin excludes her from reflecting the image of God. Mary's obedience, however, compensates for Eve's disobedience. In De cultura feminarum (1.2.5) Tertullian (died ca $220 \mathrm{CE}$ ) (see Børresen 1991a:190) addresses woman directly regarding the Fall: "You are the one who opened the door to the Devil, you first plucked the fruit of the forbidden tree and deserted divine law. You are the one who persuaded him whom the Devil was not strong enough to attack. All too easily you destroyed the image of God in man" (English translation in Børresen 1991a:190).

Christ, with the help of Mary, restored the image of God in human beings. Mary, the mother of Christ, by denouncing sex, has become the symbol of virginal purity. Through her, one sees the reflection of the "purest light" in Christ himself. Mariology did not become part of Barth's Protestant theology (see CD 1.2; cf Brown 1979:530 note31). Yet, parallel concepts of women reflecting God's image less than men are justified in Barth's gender theology - although different from that of the church fathers. Ambrosiaster (late $4^{\text {th }}$ century), an unidentified commentator on the Pauline corpus (see Børresen 1991a:192-193), was of the opinion that women were not created in the image of God, since that was an exclusively male prerogative. According to him, Adam's status of having been created in the image of God, is transferred to his male descendents. Women, on the other hand, inherit the alienation from God and subjugation which were caused by Eve. He justified his idea of women's subjugation as "God's will" with 1 Corinthians 11:7.

The exegesis of Ambrosiaster was later attributed to Ambrosius and Augustine (see Børresen 1991a:192-193), and through them found its way into Medieval Roman Catholic canon law which helped to entrench the submissive status of women in church and society. Ambrosiaster's commentary on 1 Corinthians 11:7 emphasises that women should defer to the power (imperium) of men. Because they are not the image of God, Christian women should wear a veil. First he argues that women are not image of God and then this "fact" is used to justify their submissive status in the church. Though the exegesis of Ambrosiaster differs from the Antiochean, the conclusion was the same: the domination of men over the rest of creation, including women, is ordained by God. Diodorus Tarsensis (died before 394 CE) (in Staab 1933:83-112) used 1 Corinthians 11:7, emphasises that only 


\title{
Karl Barth's male-female order as asymmetrical theoethics
}

men are the image of God because they have power over women. A similar idea can be found with Chrysostom (died 407) (see Børresen 1991a:192-193).

Over against the previous statements concerning the depravity of women from the very beginning, Clemens Alexandrinus argues that the salvation of women in Christ goes back to the very beginning of creation. Since godliness and femaleness were at the time seen to be mutually exclusive, women could not have been created in the image of God. Only if Christ's salvation had already been valid at creation, then could women have been created in the image of God. "Salvation" explicitly meant: being saved from femaleness. "Image of God" as a concept had nothing to do with a person's sex. In spite of this, Clemens Alexandrinus still describes moral and intellectual perfection as "perfect maleness". The consequences are described by Børresen (1991:196): "Clement's praise of asexual virtue and intellect in man-like disguise enhances theomorphic women by classifying them as honorary men.'

For Cyrillus Alexandrinus (see Berkowitz \& Squitier 1986:93-99) the image of God in human beings could be recognised in characteristics such as rationality, freedom, dominance, holiness, purity and sonship. The question is whether women would be included in this. According to Cyril, women essentially have the same nature as men, but there are some important differences (from Homilae Paschales 28.3, in Burghardt 1957:128-129):

\begin{abstract}
(M)an is superior, woman inferior; man holds the chief place, woman is subject and subordinate; man has greater honor and glory, even before God, whereas woman is of less esteem ... (W)oman falls short of man's "natural ability". She has not the strength to achieve the virtue of which the male is capable. She is of imperfect intelligence. Unlike her male complement she is dullwitted, slow to learn, unprepared to grasp the difficult and the supernatural; for her mind is a soft, weak, delicate thing ... On the other hand, the male sex is ever elect of God, because it is a warrior breed, because it is capable of coming to spiritual vigor, capable of sowing seed, of teaching the rest, of tracing its steps to the mature measure of the fulness of Christ.
\end{abstract}

In other words, redemption through Christ (recreation), restores authenticity. Centuries later, for Karl Barth too, recreation is seen by Christian Western tradition to be rooted in the resurrection of Christ. In this regard Robert Dawson (2007:1) refers to Barth's insight as follows:

Karl Barth (1886-1968), widely recognized as one of the greatest theologians of the twentieth century, perhaps more than any other, 
focussed his attention upon this basic conviction of Christian faith. For him, the Christian confession "Jesus is risen!" is the definitive opening statement for all Christian theology. The proclamation "Jesus Christ lives," he claims, is "at once the simplest and the most difficult christological statement" [CK IV.3.i]. This fundamental confession of the Christian church has in view the inexhaustibly rich origin and spring of all Christian knowledge. It is "the axiom of all axioms" [CD IV.1].

For Barth the resurrection is the "decisive and primordial, self-revelation of God" (Dawson 2007:3; his emphasis). According to Dawson (2007:71) the "doctrine of the resurrection held a formative place in Barth's theological understanding" (cf Torrance 1990:110, 164-167). It is clear that this "creational theology" is based on an understanding of human beings, male and female, as "the image of God". Being "the image of God" presupposes authentic existence for human beings. However, ironically enough, in the process of elaborating on the notion of "the image of God" in human beings, both the church fathers and Karl Barth rob women of authenticity.

Similar to church fathers such as Cyrillus Alkexandrinus (and Barth later), Gregorius Nyssenus (of Nyssa in Cappadosia) (see Berkowitz \& Squitier 1986 153-155) also included women in "the image of God" without respecting their God-given authenticity. This is possible because he sees "image of God" as a pre-sex privilege. The first creation was purely spiritual. To this perfect state of humanity believers will be restored by Christ's salvation. Only with the second creation did aspects such as bodiliness, mortality and sin come into play. Gregorius considered the bodiliness of both male and female as second rate (see Köstenberger 1997:111). He uses Galatians 3:28 as an example of the pre-sex image of God which will be restored by salvation. All forms of sex are excluded from the concept "image of God". For Gregory male and female names for God are inadequate. Neither "Father" nor "Mother" can be used to refer to the reality of God (see Børresen 1991a:197).

Over against the previous dualistic views on male and females, Augustine emphasises the unity of creation. He connects the differentiation of sex in Genesis 1:27b-28 with the "image of God" text in Genesis 1:26-27a. Where patristic exegesis views 1 Corinthians $11: 7$ as affirming that only males are created in the image of God, in Augustine's interpretation this text also refers to women as created in the image of God. Sullivan 1963:49) explains it as follows: 
The site of the image, the mens or the "inner man", is part of man's nature, and it was not taken away by original sin. Because the divine image is rooted in the very nature of man, Augustine will reject the opinion that woman is not equally with man an image of God. Much of eastern patristic thought - especially that of the Antiochenes from whom the note of dominion was a point of stress in the concept of the divine image - finds the image in a diminished sense in woman, or refuses to admit that woman is an image of God.

Augustine's theology had a formative influence on Karl Barth's thought on both male and female as image of God. Augustine interprets Genesis 1:27-28 as stating unequivocally that humanity in its entirety was created in the image of God. In De Trinitate, XII.7.10 he puts it as follows: "Ad imaginem Dei quippe naturam ipsam humanam factam dicit, quae sexu utroque completur." In keeping with his time Augustine, however, does consider "femaleness" and "image of God" to be mutually exclusive. According to him, women can be the image of God in spite of their physical femaleness and because of the salvation of Christ which reaches back to creation. Men, on the other hand, are the image of God because of their inherent superior spiritual maleness (see Brooten 2003:181-193).

In this respect, Barth did not go as far as Augustine. When Augustine talks about God, he invariably excludes women from that level of divinity. In Augustine's view, men and women together represent full humanity and, therefore, the image of God. A man on his own is also representative of the image of God. However, a woman alone does not represent the image of God. When men and women are seen together, the male component is superior and the female inferior. This is explained as follows in Augustine's De Trinitate 7.7.10 (translation in Coll 1994:72):

Woman together with her husband is in the image of God so that the whole substance may be one image; but when she is referred to separately in her quality of helpmate, which regards woman alone, then she is not in the image of God. But as regards man alone, he is the image of God as fully and completely as when woman is joined to him in one.

Man and woman both have a soul, says Augustine. As far as their spirituality is concerned, they share a common nature. When it comes to corporeality,

\footnotetext{
${ }^{4}$ See Stammkötter, F-B \& Müller, C (2004). s v F. als "Regel" (besonders bei A[ugustinus].s Verhältnisbestimmung von Mann und Frau), in Mayer, C (Hrsg), Augustinus-Lezikon. Vol 3 , Fasc 1/2, 49-52.
} 
however, there is a difference. Patriarchal and hierarchical sex roles are God's will and procreation is the only reason why God created woman (see Brooten 2003:181-193). If the issue was companionship for a man, another male would have been a far better companion. The restoration of perfect humanity for Augustine is not that women should become male. Women as such will partake in the resurrection from death, but they will no longer have a precreative function. They will then be free from their inherent bodily corruption. Women's bodies will no longer entice men, since men too will be free of their sinful bodiliness. "Woman" is equally creation of God, just as "man". Mary's obedience as the mother of Christ and the church's obedience as the bride of Christ assure the salvation of women (cf Børresen 1991a:202204).

Augustine's perspective was therefore more holistic than that of his predecessors - and to some extent therefore closer to Karl Barth's gender perspective. For Augustine "woman" was part of creation and "body" is part of human nature. However, maleness is still regarded as superior and everything female as inferior and of lesser value. In patristic times and in the early Middle Ages women were included in the "image of God" only on a spiritual level. At this point Karl Barth, as Protestant theologian, deviates somewhat from Augustine. According to Augustine, on a social level both married women and celibate women were under male authority: married women under their husbands and celibate women under the authority of the bishop. Though celibate women had a higher spiritual status than married woman, they could still not assume a public position of any kind (Ruether 1991:267).

Over against such a view on marriage, Friedrich Schleiermacher's "ethics of love" (see Crouter 2005:109-117; Herms 2005:209-228) shocked the European society of his day with his explicit endorsement of "inclusive love" (see Thandeka ${ }^{5}$ 2005:287-306) outside the boundaries of marriage. Karl Barth, however, could not escape the asymmetrical bias of the patristic fathers or the Medieval church.

\section{THE MEDIEVAL CHURCH}

Early Medieval exegetes of Genesis 1:27 and 1 Corinthians 11:7 often quote Ambrosiaster and then combine his views with the interpretations of Ambrosius and Augustine. In order to bring these disparate views together the commentators focus on the idea of "inclusive salvation". Woman is generally seen as image of God The exception Abelard (died 1143), according to whom woman was created "in God's resemblance, but not in [God's] image"

\footnotetext{
${ }^{5}$ Thandeka is a Associate Professor of Theology and Culture at Meadville/Lombard Theological School in Chicago and an ordained Unitarian Universalist minister and theologian. She was given the Xhosa name, Thandeka, which means "beloved", by Archbishop Desmond Tutu in 1984 (Mariňa 2005:xi).
} 
(Børresen 1991b:211-212). Ellen Ross (1990:101) evaluates this trend in Medieval views on sex and the concept "image of God" as follows:

\begin{abstract}
Despite the symbolic female/male differences wherein woman represents the physical and man the spiritual, for the most part the medieval tradition affirmed that women and men are equally images of God ... (W)e must read these medieval writers with a constant eye to patriarchal distortions, and to inconsistencies in their claims about the human person.
\end{abstract}

The Franciscan, Bonaventura (died 1274), accepts that woman was created in the image of God. The problem for him is how to explain the supremacy of the male in 1 Corinthians 11:7. His solution is then to regard man as image of God in the first place, principaliter, but not exclusively so. Barth's categorising of the male-female order of male as A and female B breathes a similar spirit of male dominance. Bonaventura reduces woman's capacity for being image of God. Women cannot be priests, because they cannot represent (representatio) Christ. According to him, men already enjoyed pre-eminence at creation. A priest shares in the power of God and that is an exclusively male prerogative. Bonaventura substantiates his point of view by citing 1 Timothy 2:12: "I do not allow her to ... teach or to exercise authority over a man." A woman could not be ordained, since that would qualify her to become a bishop, which would have been considered totally impossible. The typological argument would then be: because the bishop is the bridegroom of his church, a woman cannot be a bishop. Bonaventura combines two opposing traditional motifs in order to argue on the one hand that women are image of God in a sexless way, but on the other hand, are not fit for priesthood (see Børresen 1991b:214, 216, 218).

Thomas Aquinas was the theologian who applied Augustine's ethics of morality, sexuality, and marriage (see Brooten 2003) most exhaustively so that gender relationships in marriage became a sacrament (see Schillebeeckx 1965). According to Thomas Aquinas (died 1274), women were created in the image of God, but he nevertheless emphasises the primacy of men. The subordination of women is the result of their weakness in reason and bodiliness (see Mackin 1982:32). The female person is imperfect because she has not yet reached a state of "authentic humanity" as men have. The female aspect is necessary in order to complete humanity. With the resurrection, women will finally be rid of their female defects. Here, as in the case of Karl Barth's theology, the "doctrine of resurrection" functioned decisively for Thomas - in a primordial [fixed since creation] manner (cf Dawson 2007:3). Essentialistic primordialism (see Ward 1997:136) sees some aspects of 
human reality as "God-given" creations rather than social constructs. Biosocial aspects are mystified as divine creation ordinances, such as, for example the institution of marriage with it asymmetrical gender relations.

Thomas's reason why women cannot be priests is not because they cannot represent Christ physically, but is bio-social. Women are physically inferior and therefore are subordinate to men. That is why they also cannot be priests. Physical excellence is needed in order to be a priest. Thomas Aquinas does see woman as the image of God (see Børresen 1991b:218, 221, 224). He distinguishes between women and slaves. Slavery is not part of the order of creation, but is the result of sin and is only tolerated because it is necessary for upholding the social order. The male-female hierarchy, on the other hand, is part of the order of creation (see Coll 1994:72). The Benedictine abbess, Hildegard of Bingen (died 1179), also rejects the possibility that women could be priests. Because of their weakness and their passive role in procreation, women cannot celebrate the sacraments (see Børresen 1991b:225).

During the Renaissance the Aristotelian view that woman is no more than a "deviant man" changed. The female sex was now seen as normal and natural, yet weaker and more fragile than the male sex. Therefore females needed to be protected (see Maclean 1980:28-46). The Aristotelean idea the the fetus was the result of male seed only, also changed. The contribution of the woman was accepted (see Maclean 1980:35-37).

Other issues of the day were whether women were competent to rule, whether it would be God's will if they would, and what their relationship to men would then be (Douglass 1991:228-229). Some women, such as queens and members of the nobility, had substantial power. Witch hunts on women who had too much knowledge (power), continued until well after the Reformation (Coll 1994:73). Two Dominicans, Kramer and Sprenger, who were commisioned by the pope to document the regulations against witchcraft put it as follows: "All witchcraft comes from carnal lust which is in women insatiable" (Summers 1971:123; cf Daly 1979; Dworkin 1974).

\section{THEOETHICS FOR AN ONGOING STORY}

The sacramentalisation of marriage in the Medieval church forms the apex of a socio-religious institutionalisation and the reification of sexual intimacy together with asymmetrical theoethics. It has become clear that, since early Christianity, through the Medieval Church, women were demeaned by some and praised by others. A prevalent question was whether women's weakness was inherent or the result of socialisation, including insufficient education and little experience outside of the house (see Kelly 1982; Douglass 1985:66-73). In 1598 a dissertation titled $A$ new dispute about women appeared in which it 


\title{
Karl Barth's male-female order as asymmetrical theoethics
}

was proven that women were not human. This document is usually attributed to Valens Akidalius. It is was a satirical piece which was seriously debated by doctors, jurists and theologians. The text and protests against it, were published until the eighteenth century (cf Maclean 1980:12-13; Fleisher 1981).

What theoethics needs to accomplish today, is to expose male dominance and conscientisation of the insight that sexual relations - also gender relations as such - are social constructs. During the twentieth century, Barth's Church Dogmatics provided new solutions for many theological impasses cause by the Enlightenment (see e g, Webster 1981:31-35; 1994:35-52; 1995, 1998, [2000] 2004). His notion of "Christian freedom" in Christian ethics is one of these contributions. Ethics is about investigating the spheres in which ethical guidelines are sought. According to Barth, final answers can never be given, since that would amount to a restriction of God's freedom of action (Ford 1984:80). If ethics refrains from attempting to give "absolute" and final answers, the freedom of humanity to choose fellowship with God, will also be safeguarded. According to Hegel's [1986] "philosophy of right", (in his Phänomenologie des Geistes, Werke 3) freedom is attained when social life is structured and ordered by the state (see Henrich [1967] 1971). Similarly, in his theoethics with its emphasis on "natural moral law" and "divine creation ordinances", Barth rooted freedom both in the order of creation and in an orderly social dispensation. Ford (1984:83) puts it as follows:

\begin{abstract}
Barth's special ethics of the doctrine of creation denote God's command for the ordering of creaturely relationships, particularaly the male-female relation. God commands; humanity responds. God commands a divinely ordered relational sequence for male-female. It is a sequence which states a particular order, for humanity to live as male and female with one another. It is an order of $\mathrm{A}$ and $\mathrm{B}, \mathrm{a}$ prescribed order for co-humanity (Mitmenschlichkeit) to live as male and female. Observance of this prescribed order is to ensure freedom for all humanity as commanded by God.
\end{abstract}

Because this order of man as $A$ and woman as $B$ (CD III.4) is set in creation, it is fixed. It is an order of succession: $A$ comes before $B$ and $B$ follows $A$. Therefore it is the man's prerogative to lead and initiate. The woman should follow male leadership, because by doing so, she co-operates in establishing the "right" relationship (so ordered by God) between male and female. This order also determines the functions of the sexes. The difference between male and female does not necessarily lie in their nature or essence, according to Barth. The difference lies in the order and therefore in their functions. Ford (1984:87) puts it as follows: "There is a functional inequality in this order as only the man can lead and the woman must follow ... Barth in effect establishes a hierarchy in the male-female relationship in terms of the super- 
ordination of man over woman." Such a hierarchy is paternalistic and precludes mutuality.

John C Bennett (1962:75-77) criticises Barth's view as follows: "I do not know what Barth makes of concrete situations in which women may be the 'inspirer, leader and initiator' and I see in him a failure to grasp the possibilities of mutuality in decision as between men and women." Bennett calls this "refined patriarchalism". For Barth the woman's "freedom" lies in the fact that she should take up this given (ordered) position voluntarily. Ford (1984:88) criticises it emphatically as "not genuine freedom since it is based on an internalized socialization into patriarchal patterns which the man as $A$ as initiator upholds and to which the woman as B as follower acquiesces. The function of woman as B as only a follower in this structured order severely truncates her whole personhood." Woman was therefore created the follower. In all her relationships this is "her place". She follows God, Christ, the church, social authorities, her father, her husband. Only as a mother does she take the initiative, but then also under the overall leadership of her husband (see Ruether 1978:53-59).

This male-female relationship established by Barth, is then used as analogy for the relationship between Christ and human beings. Barth does expressly state that males should not exploit this order and position above women. Such behaviour would not be in accordance with the divine order. Like some theologians before him, who contextualised their insights in the matrix of "Western Christian tradition", Barth also maintain that, in essence, man and woman are equal. However, they are distinguished on account of their functions. He does not conform to traditionalist ideas of the inherent inferiority of women, such as can be seen by Plato, Aristotle and Thomas Aquinas (see Ruether 1991:45). Yet, he limited the hierarchical order to social reality where it is simply a given that man is above woman, parents are above children, masters above servants and clergy above laity.

Barth's discussion on the nature of human beings, man and woman, sound egalitarian. He describes them as having equal dignity and being of equal worth and value. The difference lies only in their roles. When this difference is introduced, however, equality falls by the wayside, and along with it equal dignity, worth and value. What in effect happens, Ford (1984:93) points out, is that "Barth has really only shifted his basis for patriarchal hierarchy from essence to function." This is underlined by his use of the order of man first and woman second, as the analogy for the relationship between God and humanity: God first and humanity/creation second (see Mercandante 1978:80-81). 
According to Barth's critics the two categories of humanity (men and women) on the one hand, and God in relationship with people on the other, are too different to equate by means of analogy. Emma Jutes (1978:52) points out that what he in effect does, is to "mix apples and oranges". One cannot use a relationship between created beings to reflect the relationship between the Creator and created beings. There are consequences: "The apples and oranges are mixed up and the result is misleading: man begins to look more like God than the human being he is. And Barth provides fuel for a tyranny which he has tried to defeat" (Jutes 1978:52-53). The relationship between Creator and created beings cannot be analogous to the relation between men and women. Barth, however, does make the analogy between God and Israel, Christ and the church, male and female and puts it as follows: "In the gospel of Christ there is the deepest root of this precedence and succession, this superiority and inferiority in relation of male and female" (CD III.4.172-174).

Ford (1984:96) points out that there is and inconsistency in Barth's doctrine of creation. What he sets out to do is highlight mutuality and cooperation between the I and Thou in Elohim, between God and God's creatures, between Christ and humanity and in male and female relationships. What he achieves, however, is to establish a hierarchical structure of superand subordination rather than an egalitarian relationship.

Woman's subordination to man is similar to Christ's obedience to God. To see God as obedient, Barth (CD IV.1.202-203) calls an "astounding conclusion". But, the fact is that Jesus was obedient, and he was so "in humility". On the grounds of this Barth is therefore able to take the step of establishing an analogy to the relationship between man and woman. He finds that women should accept their "ordained" status with humility equal to that of Christ. Ford (1984:98) criticises this. According to her, Christ's obedience to God cannot be analogous to women's subordination to men. Christ represents God and humanity in his own person. What he does for human beings on the cross is to reconcile them with God - something human beings could not do. Barth's analogies structure subjugation and subordination by which he is untrue to his own idea of Mitmenschlichkeit (co-humanity), which is the free and voluntary co-operation and service of men and women to one another (Ford 1984:102). The application of the analogy of the relationship between God and Christ to the relationship between man and woman amounts to the creation of a hierarchical relationship among God's creatures. Ford (1984:103) points out that this represents an "inconsistency in Barth's own thought". Elsewhere Barth (CD III.1.231) makes much of the partnership between God and the creatures of creation. The covenant is the goal of 
creation. It is based on the free love between the Father and the Son, which is extended to humanity.

Barth (CD III.2.313) sees Ephesians 5:22-23 as the locus classicus for the relationship between man and woman. In this passage of Scripture the relationship of man and women is directly related to that of Christ and the faith community. Barth puts it as follows: "From it [Eph 5] we can survey the whole landscape which we have traversed: the New Testament relationship of man and woman in the light of the relationship between Christ and the community, and conversely the elucidation of the relationship between Christ and his people by the reference to the man-woman relationship" (Barth CD III.2.313). This passage emphasises the subordination of woman. Barth does not regard it as a problem since in her subordinate position woman has the "status" of representing the church as it stands in relationship to God. Her husband does not have this "privilege". Barth (CD III.2.315-316) explains the connection with Genesis 2:18-25 as follows:

For the creation of man and for this climax, for this form of humanity [as male and female] the normative pattern, the basic decree and plan of all plans of God is "Christ and the community." This stands inaccessibly before and above the copy of man and woman. Manwoman relationship is a little "copy" of the relationship between Christ and the Church.

Ford (1984:112) criticises the analogy between Christ and the faith community to man and woman as erroneous. On the one hand the human relationship between men and women cannot adequately reflect the relationship between God and creatures, of Christ and the faith community. On the other hand that would mean that the subordination of one creature to another is grounded in Christ - which is untenable. Ford (1984:112) strongly criticises Barth: "We must note that Barth errs as he accepts the patriarchal bias in Scripture to see that woman is analogous to the Church." She contends that Barth's analogous use of this typology violates the whole personhood of women. Ruether (1978:56) points to the consequences:

But this same analogy, read back as normative for marriage and social relations, shows its limiting effects for women. The analogy confines women to only one type of personality development: Submission in relation to God, clergy, and husband. Men, on the other hand, are allowed to develop their personalities out of both sides of the analogy. They cultivate female traits in relation to God or divinely ordained authority figures over them but they can also cultivate the traits of lordship over women and children or servants, for whom they represent God's Word. 


\section{Karl Barth's male-female order as asymmetrical theoethics}

According to Ford, Jürgen Moltman (1981), with his panentheistic view of the Trinity, paves the way for a new ethic for the relationship between men and women. Ford (1984:200-201) built on this to construct a new ethic in the model of Jesus as liberating friend. In the idea of friendship, mutuality supercedes dominance in the relationship between Jesus and the faithful as well as in that between men and women. Ford (1984:201) contends that with such an image an anthropology of wholeness, equality and mutuality between men and women can become a reality in church and society.

\section{EPILOGUE}

Theologians today are challenged by gender criticism to reconstruct images of God based on a fair anthropological basis. The present-day renaissance of "Barthian" theology is not conducive to providing space for the full realisation of human potential for women and men. The critical question should be: which human projections about God lead to injustice and a diminished humanity for some and which contribute to the full humanity of all people (Ruether 1991:277). Constructs such as theological and anthropological theories are not innocent or harmless. On the one hand history has shown how they functioned to influence social structures, and on the other hand to legitimate social structures. Culture forms our humanity. People inherit the norms and ways of thinking of their society and internalise them. They become part of how people define themselves. Often people are unaware of the negative aspects which are inadvertently absorbed. In the case of women in particular, the process of the internalisation of negative messages goes as follows:

Es scheint, daß alle üblichen Vorstellungen über die Frau als das
Negative vom Mann oder als seine Gehilfin: "Mutter von ...", "Frau
von ...", "Tochter von ...", "Mätresse von ..." mit all ihren
entsprechenden sozialen Realitäten, die Frauen produziert und
reproduziert haben, gebildet wurden, weil dies die Modelle waren,
nach denen sie ihre Identiät geformt haben.

(Mulder 1996:72)

Not only women are hurt when systems dehumanise people. A dehumanising system will affect those with less and those with more power, only in different ways. Coll (1994:82) puts it as follows: "When the systems operative in a culture are demeaning and dehumanizing, a vicious circle is set in motion in which women and men are prevented from developing the full humanity to which they are called. At the same time fractured humanity is incapable of creating a society that is truly human." 
In order for human beings to create a "humane" society, it is important to remain critical of the dehumanising status quo. In order to open up the possibility of authentic humanity for all people it is necessary to be aware that constructs and social patterns are human creations, not God-given structures. These human creations have the potential to do harm or be evil. Leroy Howe (1995:23) puts it as follows:

Central to a Christian understanding of human existence is the conviction that God is at work re-creating the whole of humanity as a single family whose members share a common calling to care for the created order. But our sense of partnership wanes with the failure to restrain our impulses to dominate, and solidarity with all human beings is everywhere eclipsed by oppression and enslavement. Nevertheless, we continue to yearn for a truly caring society as the harvest of a genuinely meaningful historical process.

The possibility of social constructs which are either theologically presented as "the will of God" or simply accepted as "the way it is", to harm people, should be critically investigated. People should be aware and make others aware of the harmful potential of human social constructs and theologies. Awareness can lead to change. The aim is that all people should be able enjoy an authentic life before God.

\section{Works consulted}

Barth, K [1918] 1933. The Epistle to the Romans, tr by E C Hoskins from the $6^{\text {th }}$ German edition. Oxford: Oxford University Press.

Barth, K 1932-1969. Die Kirchliche Dogmatik, 4 volumes. München: Chr Kaiser Verlag.

Barth, $\mathrm{K}$ 1933. The Epistle to the Romans, tr from the $6^{\text {th }}$ edition by E C Hoskins. Oxford: Oxford University Press.

Barth, K 1934-1964. Church Dogmatics, 4 volumes, tr by G W Bromiley et al. Edinburgh: T \& T Clark.

Barth, K 1953. Die Auferstehung der Tote: Eine akademische Vorlesung über I, Kor 15. Zürich: Evangelisher Verlag.

Beiser, F C 2005. Schleiermacher's ethics, in Mariňa, J (ed), The Cambridge companion to Friedrich Schleiermacher, 58-72. Cambridge: Cambridge University Press.

Bennet, J C 1962. Review of Church Dogmatics III/4 by Karl Barth. Union Seminary Quarterly Review 18(1), 74-79.

Berger, P L 1979. The heretical imperative: Contemporary possibilities of religious affirmation. Garden City, NY: Doubleday.

Berkowitz, L \& Squitier, K A (eds) 1986. Thesaurus Linguae Graecae: Canon of Greek authors and works. New York: Oxford University Press.

Bourquin, D 1972. Barthian theoethics: Review of the ethics of Karl Barth by Robert Willis. Christian Century 7, 673. 
Bromiley, G W 1979. An introduction to the theology of Karl Barth. Grand Rapids, MI: Eerdmans.

Brooten B J 2003. Nature, law, and custom in Augustine's On the good of marriage, in Matthews, $\mathrm{S}$ et al (eds), Walk in the ways of wisdom: Essays in honor of Elisabeth Schüssler Fiorenza, 181-193. Harrisburg, PA: Trinity Press International. (A Continuum Imprint.)

Brown, $\mathrm{R} E$ 1979. The birth of the Messiah: A commentary on the infancy narratives in Matthew and Luke. New York: Doubleday.

Buitendag, J 1986. Die skepping as gelykenis: 'n Beoordeling van die skeppingsleer van Karl Barth in die lig van die appèl van die ekologiese krisis. HTS 42(4), 674-695.

Buitendag J 2007. Marriage in the theology of Martin Luther - worldly yet sacred: An option between secularism and clericalism. HTS 63(2), 445-461.

Burghardt, W J 1957. The image of God in man according to Cyril of Alexandria. Washington, D C: The Catholic University of America Press. (The Catholic University of America Studies in Christian Antiquity 14, ed by Johannes Quasten.)

Coll, R A 1994. Christianity and feminism in conversation. Mystic, CT: Twenty-Third Publications.

Crouter, R 2005. Friedrich Schleiermacher: Between enligthenment and romanticism. Cambridge: Cambridge University Press.

Daly, M 1979. Gyn/Ecology: The metaethics of radical feminism. Boston, MA: Beacon.

Dawson, R D 2007. The resurrection in Karl Barth. Hampshire: Ashgate. (Barth Studies.)

Deegan, D 1962. Review of Church Dogmatics by Karl Barth, III/4. Scottish Journal of Theology 15(4), 400-412.

Douglass, J D 1985. Women, freedom, and Calvin. Philadelphia, PA: Westminster.

Douglass, J D 1991. The image of God in women as seen by Luther and Calvin, in Børresen, K E (ed), Image of God and gender models in Judaeo-Christian tradition. Oslo: Solum Forlag.

Dreyer, Y 2007. Karl Barth's male-female order: A kingpin of dogmatic disparity. HTS 63(4), 1523-1547.

Dworkin, A 1974. Woman hating. New York: E P Dutton.

Ellison, J 1990. Delicate subjects: Romanticism, gender and the ethics of understanding. Ithaca, NY: Cornell University Press.

Evans, G A, Webb, R L \& Wiebe, R A (eds) 1993. The teachings of Silvanus, in Nag Hammadi texts \& the Bible: A synopsis \& index, 313-335. Leiden: Brill. (New Testament Tools and Studies.)

Evans, G A, Webb, R L \& Wiebe, R A (eds) 1993. The Gospel of Thomas, in Nag Hammadi texts \& the Bible: A synopsis \& index, 88-144. Leiden: Brill. (New Testament Tools and Studies.)

Fleisher, M P 1981. Are women human?: The debate of 1595 between Valens Acidalius and Simon Geddicus. Sixteenth Century Journal 12, 107-120.

Ford, J C 1984. Toward an anthropology of mutuality: A critique of Karl Barth's doctrine of the male-female order as $A$ and $B$ with a comparison of the panentheistic theology of Jurgen Moltmann. Unpublished PhD dissertation. Northwestern University, Ann Arbor, Michigan, USA. 
Franzmann, M 1996. Jesus in the Nag Hammadi writings. Edinburgh: T \& T Clark.

Gasparro, G S 1991. Image of God and sexual differentiation in the tradition of enkrateia, in Børresen, K E (ed), Image of God and gender models in JudaeoChristian tradition. Oslo: Solum Forlag.

Goodspeed, E J (ed) 1915. Tatianus, Oratio ad Graecos, in Die ältesten Apologeten, 268-305. Göttingen: Vandenhoeck \& Ruprecht.

Görgemanns, H \& Karpp, H (eds) 1976. Origenes, De principiis, in Origenes vier Bücher von den Prinzipen. Darmstadt: Wissenschaftliche Buchgesellschaft.

Hartwell, H 1964. The theology of Karl Barth: An introduction. Philadelphia, PA: Westminster.

Hegel, G W F [1986]. Phänomenologie des Geistes: Werke in 20 Bänded, Werke 3. Frankfurt: Suhrkamp.

Henrich, D [1967] 1971. Hegel im Kontext. Vierte, veränderte Auflage. Frankfurt: Suhrkamp.

Herms, E 2005. Schleiermacher's Christian ethics, in Mariňa, J (ed), The Cambridge companion to Friedrich Schleiermacher, 209-228. Cambridge: Cambridge University Press.

Jüngel, E 1982. Theologie als Metakritik: Zur Hermeneutik theologischer Exegese, in Barth-Studien, 91-98. Zürich: Benziger Verlag.

Jutes, E J 1978. Theological reflections on the role of women in church and society. The Journal of Pastoral Care 32(1), 42-54.

Kelly, J 1982. Early feminist theory and the Querelle des Femmes, 1400-1789. Signs 8, 4-28.

King, K 2003. The Gospel of Mary of Magdala: Jesus and the first woman apostle. Santa Rosa, CA: Polebridge.

Lauster, J 2004. Prinzip und Methode: Die Transformation des protestantischen Schriftprinzips durch die historische Kritik von Schleiermacher bis zur Gegenwart. Tübingen: Mohr Siebeck. (Hermeneutische Untersuchungen zur Theologie.)

Mackin, T 1982. What is marriage? New York: Paulist.

Maclean, I 1980. The Renaissance notion of woman: A study in the fortunes of scholasticism and medical science in European intellectual life. Cambridge: Cambridge University Press.

Macquarrie, J 1990. Jesus Christ in modern thought. Philadelphia, PA: Trinity.

Stammkötter. F-B \& Müller, C 2004. s v F. als "Regel" (besonders bei A[ugustinus].s Verhältnisbestimmung von Mann und Frau), in Mayer, C (Hrsg), AugustinusLezikon. Vol 3, Fasc 1/2, 49-52. Basel: Schwabe Verlag.

Markschies, C [2001] 2003. Gnosis: An introduction, tr by J Bowden. London: T \& T Clark.

McKelway, A J 1979. The concept of subordination in Barth's special ethics. Scottish Journal of Theology 32(4), 345-357.

Mercandante, L 1978. From hierarchy to equality. Vancouver, BC: GMH Books.

Mercandante, L 1979. The future of creation: Collected essays, tr by M Kohl. Philadelphia, PA: Fortress.

Migne, J-P [1963] 1974. Patrologiae Cursus Completus, Supplementum, Volume V. Series Latina. Paris: Editions Garnier Freres.

Moltmann-Wendel, E \& Moltmann, J 1981. Seeming human in new community. The Ecumenical Review 33, 354-365. 
Mulder, A C 1996. Überlegungen zur "Imago Dei”: Minimalisierung oder Maximalisierung der Differenz zwichen den Geschlechtern, in Günter, A (Hrsg), Feministische Theologie und postmodernes Denken: Zur theologischen Relevanz der Geschlechterdifferenz. Stuttgart: Kohlhammer.

Nautin, P \& Doutreleau, L (eds) 1976/1978. Dydymus Caecus, In Genesim, in Didyme l'Aveugle: Sur Genesé 1 (1976):32-332; 2 (1978:8-238). Paris: Cerf. (Sources Chrétiennes 233, 244.)

Poland, L 1985. The new criticism, Neoorthodoxy, and the New Testament. Journal of Religion 65.

Origenes [s a]. De Principiis III.IV.1, in Görgemanns, H \& Karpp, H (Hrsg) 1976, Origenes vier Bücher von den Prinzipien von den Prinzipien, 462-560, 668764. Darmstadt: Wissenschaftliche Buchgesellschaft.

Osiek, C 2005. Diakonos and prostasis: Women's patronage in Early Christianity. HTS 61(1\&2), 347-370.

Osiek, C 2006. New Testament teaching on family matters. HTS 62(3), 819-846.

Rae, S H 1972. Gospel, law and freedom in the theological ethics of Karl Barth. Scottish Journal of Theology 25(4), 412-422.

Richardson, R D 1991. Schleiermacher's Vertraute Briefe: A momentary aberation or a genuine Schleiermacherian ethical treatise?, in Meckenstock, G (hrsg), Schleiermacher und die wissenschaftliche Kultur des Christentums, 455-472. Berlin: De Gruyter.

Ricoeur, P 1979. Naming God. Union Seminary Quarterly 34.

Ross, E M 1990. Human persons as images of the divine: A reconsideration, in Bach, A (ed), The pleasure of her text: Feminist readings of biblical and historical texts, 97-116. Philadelphia, PA: Trinity.

Roukema, R 1998. Gnosis \& geloof in het vroegste Christendom: Een inleiding tot de gnostiek. Meinema: Zoetermeer.

Ruether, R R 1991. Imago Dei, Christian tradition and feminist hermeneutics, in Børresen, K E (ed), Image of God and gender models in Judaeo-Christian tradition. Oslo: Solum Forlag.

Sagnard, F (ed) [1948] 1970. Clemens Alexandrinus, Excerpta ex Theodoto, in Clément d'Alexandrie Extraits de Théodoté, 2nd edition, 52-212. Paris: Cerf. (Sources Chrétiennes 23.)

Schade, L (Hrsg) 1914. Ausgewählte historische, homiletische u. Dogmatische Schriften des heiligen Kirchenvaters Eusebuis Hieronymus, aus dem latyeinischen übersetzt. München: Kösel. (Bibliothek der Kirchenväter.)

Schillebeeckx, E 1965. Marriage: Human reality and saving mystery. London: Sheed \& Ward.

Smend, R 1966. Nachktritische Schriftauslegung, in Busch, E (Hrsg), Parrhesia: Karl Barth zum achtigsten Geburtstag, 215-237. Zürich: EVZ Verlag.

Staab, K (Hrsg) 1933. Diodorus Trasensis, in Pauluskommentar aus der griechischen Kirche aus Katenenhandschriften gesammelt, 83-112. Münster: Aschendorf.

Stählin, O, Früchtel, L \& Treu, U (eds) 1960/1970. Clemens Alexandrinus, Stromata, in Clemens Alexandrinus, 2 volumes (2, $3^{\text {rd }}$ edition; $3,2^{\text {nd }}$ edition), Die griechischen christlichen Schriftsteller 52(15), 17:2(1960), 3-518; 3(1970), 3102. Berlin: Akademie-Verlag. 
Stiver, D R 2007. Felicity and fusion: Speach act theory and hermeneutical philosophy, in Vanhoozer, K \& Warner, M (eds), Transcending boundaries in philosophy and theology: Reason, meaning and experience, 145-156.

Hampshire: Ashgate.

Sullivan, J E 1963. The image of God: The doctrine of St Augustine and its influence. Dubuque, IA: Priory.

Summers M 1971. Malleus Malificarum, tr by Montaque Summers. New York: Dover.

Sykes, S 1982. Barth and the power of the word. Philadelphia, PA: Fortress.

Taylor, C 2007. What is secularity? in Vanhoozer, K \& Warner, M (eds),

Transcending boundaries in philosophy and theology: Reason, meaning and experience, 57-76. Hampshire: Ashgate.

Thandeka 2005. Schleiermacher, feminism, and liberation theologies: A key, in Mariňa, J (ed), The Cambridge companion to Friedrich Schleiermacher, 287306. Cambridge: Cambridge University Press.

Thatcher, A 1999. Marriage after modernity: Christian marriage in postmodern times. Sheffield: Sheffield Academic Press. (Studies in Theology and Sexuality 3.)

Torrance, T F 1976. Space, time and resurrection. Grand Rapids, MI: Eerdmans.

Torrance, T F 1990. Karl Barth: Biblical and evangelic theologian. Edinburgh: T\&T Clark.

Tribble, P 1978. God and the rhetoric of sexuality. Philadelphia, PA: Fortress.

Van Aarde, A G 2005. The infancy gospel of Thomas: Allegory or myth? - Gnostic or Ebionite? Verbum et Ecclesia 26(3), 826-850.

Vogt, K 1991. Becoming male: A gnostic and early Christian metaphor, in Børresen, $\mathrm{K} \mathrm{E}$ (ed), Image of God and gender models in Judaeo-Christian tradition. Oslo: Solum Forlag.

Von Balthasar, H U 1971. The theology of Karl Barth, tr by J Drury. New York: Holt, Reinhart \& Winston.

Wallace, M I [1990] 1995. The second naiveté: Barth, Ricoeur, and the New Yale Theology. Macon, GA: Mercer University Press. (Studies in American Biblical Hermenutics 6.)

Ward, G 1997. Postmodernism. London: Hodder Headline. (Teach Yourself.)

Warner, M 2007. Introduction, in Vanhoozer, K \& Warner, M (eds), Transcending boundaries in philosophy and theology: Reason, meaning and experience, 1-14. Hampshire: Ashgate.

Weber, O [1963] 1967. Karl's Barth's Kirchliche Dogmatik: Ein einführender Bericht. 6. Auflage. Neukirchen-Vluyn: Neukirchener Verlag.

Webster, J B 1981. Recent work on Barth since 1975. Themelios 7(3), 31-35.

Webster, J B 1994. Assured and patient and cheerful expectation: Barth on Christian hope as the church's task. Toronto Journal of Theology 10, 35-52.

Webster, J B 1995. Barth's ethics of reconciliation. Cambridge: Cambridge University Press.

Webster, J B 1998. Barth's moral theology: Human action in Barth's thought. Grand Rapids, MI: Eerdmans.

Webster, J B [2000] 2004. Karl Barth. 2nd edition. New York: Continuum. 